\title{
Male Reproductive System Cancer TNM
}

\section{Finding v8}

National Cancer Institute

\section{Source}

National Cancer Institute. Male Reproductive System Cancer TNM Finding v8. NCI

Thesaurus. Code C140043.

A finding about one or more characteristics of male reproductive system cancer,

following the rules of the TNM AJCC v8 classification system. This classification system applies to penile cancer, prostate cancer, and testicular cancer. 